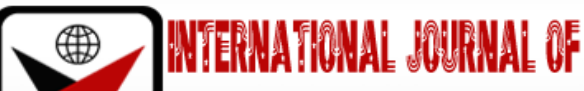

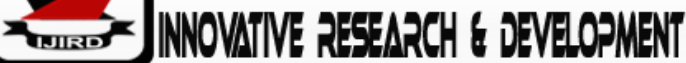

ISSN 2278-0211 (Online)

\section{Abutment Failure and Remedy in Gombe State Nigeria}

Musa Kyauta
Research Officer, Department of Road Research,
Victor Mlanga
Nigerian Building and Road Research Institute (NBRRI), Nigeria
Research Officer, Department of Road Research,
Nigerian Building and Road Research Institute (NBRRI), Nigeria
Aliyu Akilu
Research Officer, Department of Road Research,
Nigerian building and Road Research Institute (NBRRI), Nigeria
Alhassan Iko David
Research Officer, Department of Building Research,
Nigerian Building and Road Research Institute (NBRRI), Nigeria

\begin{abstract}
:
Fixed and free ends Abutment is a significant issue affecting the overall reliability and safety of a Bridge structure if not design and constructed as functioned. However, despite considerable consequences, potential functionalities of abutments in bridge structure are usually not fully considered and so abutments are generally designed as free end elements. The research presented in this paper, aimed to develop a better understanding of free and fixed ends abutment stability from both analysis and design point of view. This paper includes a case study of a Kwadon Liji Kurba bridge (GPS N10 $16.642^{\prime}$ E11 $13.520^{\prime}$ ), located at Gombe-Biu road in Gombe, Gombe state Nigeria, which was shot down for traffic used due to abutment failure. This paper presents a full result on bridge abutments analysis and design. Moreover, a systematic methodology was implemented, to identify potential remedial options for treatment of abutment movement. Considering similar loading condition as exited bridge, analysis shows a moment maximum of the fixed abutment to be $1748.79 \mathrm{kNm}$ and minimum moment at fixed end to be $631.08 \mathrm{kNm}$ and the free end abutment has a maximum moment of $2059.02 \mathrm{kNm}$. The moment is considerable large and will result to reinforcement design rather than just mass concrete abutment as in the existing bridge. The pressure exerted by the abutment was $422.35 \mathrm{kNm}^{2}$ maximum and FS against sliding of 2.8. Unless the bearing pressure of the soil greater than that, earth movement is unavoidable and so pile foundation should be used instead of spread footing.
\end{abstract}

Keywords: Abutment, functionality, failure, analysis, design

\section{Introduction}

Abutment Failure is a usual trend affecting the overall functionality of a bridge structure. This renders the lives of users at rick, if the bridge eventually collapses as a result of poor design and construction or lack of immediate remedy after investigation. Some bridges of this similar defect severely deflected and are shot down because they became a future threat to eventual collapse and so are unfit for use. Child D. (2019)

Abutment is a structure at the ends of a simply supported or a continuous spanning bridge system with a multipurpose of embanking earth pressures, axial moving loads, dead loads of the super structure and sometimes hydrostatic pressures. Abutment should be free end on one side to allow a horizontal movement of bridge beam deck system due to moving, impact loads as well as expansion of structural members and should also be fixed end on the other side to restrain neither horizontal nor vertical movement of the bridge beam deck system to achieve maximum service stability. Therefore, the functionality of Abutment in analysis, design and construction respectively, is a matter of concern which required an urgent attention in the construction industry. Robert, Kam, Ram \& Joshua (2015)

The bridge in the case study failed due to a similar problem as stated above. The failed bridge is a simply supported bridge beam deck system, saddle with an unreinforced mass concrete abutments structure with both ends fixed on spread footing base. The paper presents a remedy to abutment failure by using a similar parameter and loading condition of the study area through a critical structural analysis, considering functionality and also adherence to British standard in order to serve as guide for further abutment design in the construction industry.

Finally, the failure of Kwando LijiKurba Bridge Gombe, Gombe State has prompted the need for this research work, following a routine visual inspection of Nigeria bridges under the mandate of Nigeria Building and Road Research Institute. Kwando Liji Kurba Bridge Gombe, Gombe State is a bridge that was shot down to traffic due to Abutment failure. 
The bridge is a composite bridge, over a flood plain, comprises of both steel and concrete members. It consists of 5 Isection universal steel beam spreading $9 \mathrm{~m}$ width and accommodating 2 lanes of traffic and two pedestrian walkways. It is a 23 m length of simply supported spanned beams over abutment on both ends. The abutments are mass concrete of a trapezoidal shape with 1-meter minimum thickness at the top.

\subsection{Aim}

This research work is aimed at proffering the most practical solution in bridge abutment design, considering functionality as well as the effective loading condition of the bridge with regards to durability and affordability.

\subsection{Objectives}

- To determine the parameters of a failed abutment Located at Kwadon Liji Kurba Gombe State Nigeria.

- To re-design a failed abutment, in accordance to British Standard.

\section{Location of Kwadon Liji Kurba Bridge (Case Study Area)}

The case study in this paper is a 10 -year-old steel beam and slab superstructure road over bridge, at Kwadon Liji Kurba bridge (GPS N10 $16.642^{\prime}$ E11 $13.520^{\prime}$ ), located at Gombe-Biu road in Gombe, Gombe state Nigeria.

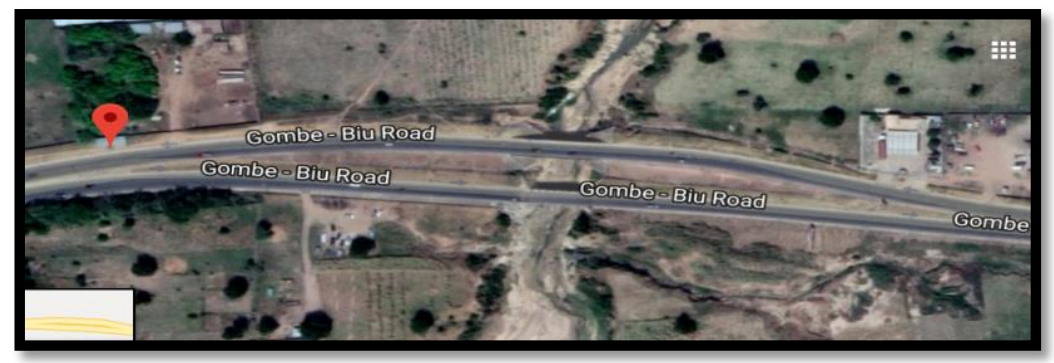

Figure 1: Location of Kwadon Liji Kurba Bridge Site taken from Google map

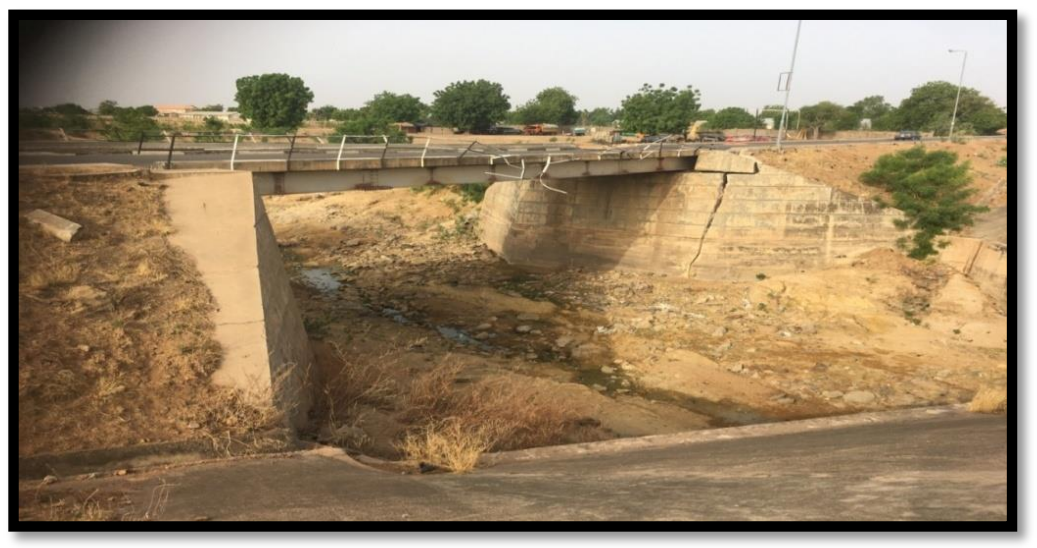

Figure 2: Image Showing Tilted Abutment

\subsection{Site Visit}

Inspection was carried out on the shut-down bridge which is on a Federal Highway. Photographs, measurement and sketches were conducted. Problem attributed to the bridge deck are road approaches and often the most obvious to the inspecting engineers as they are easily identifiable and apparent. An extensive crack appeared on both the section of the road passing both 2 lanes sides. The abutment movement is obvious upon inspection as a severe crack occurred at the west side abutment which seem to be originally from embanked rock boulders replaced after road drains delivers it flood against the unprotected embanked material and wash it off.

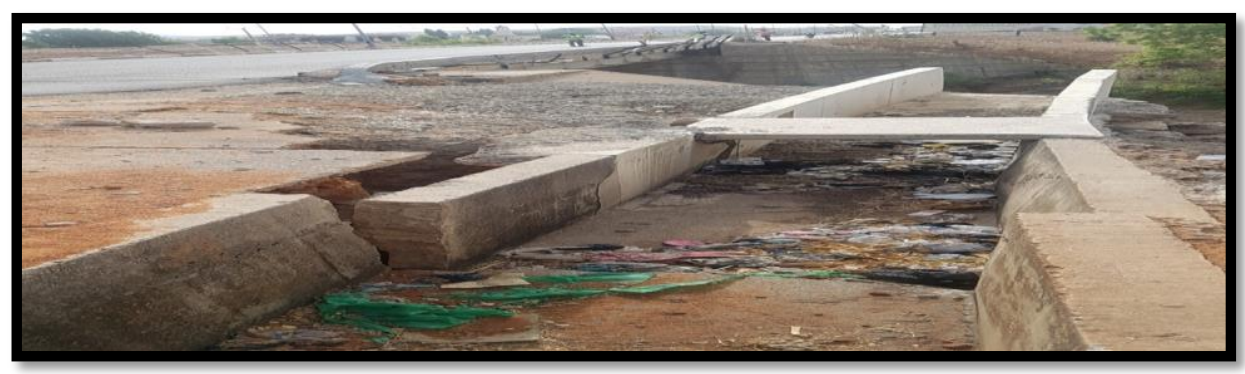

Figure 3: Image Showing Drainage Effect against the Abutment 


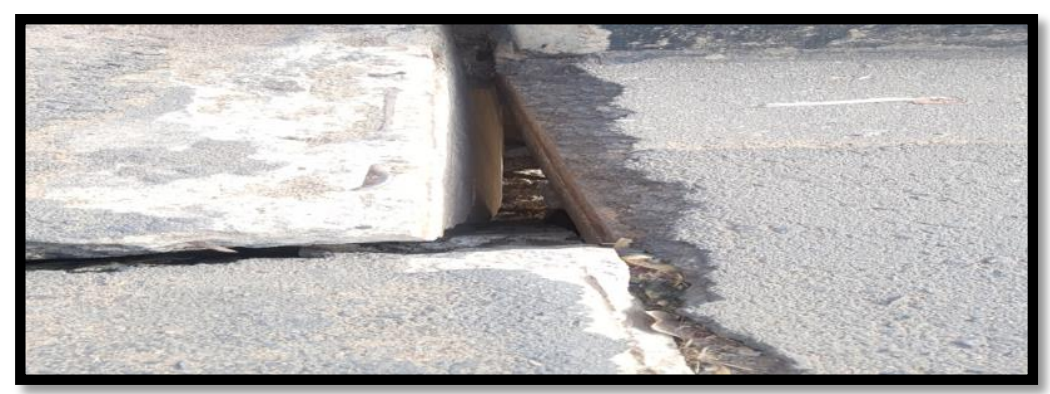

Figure 4: Image Showing Abutment Movement from Bridge Deck

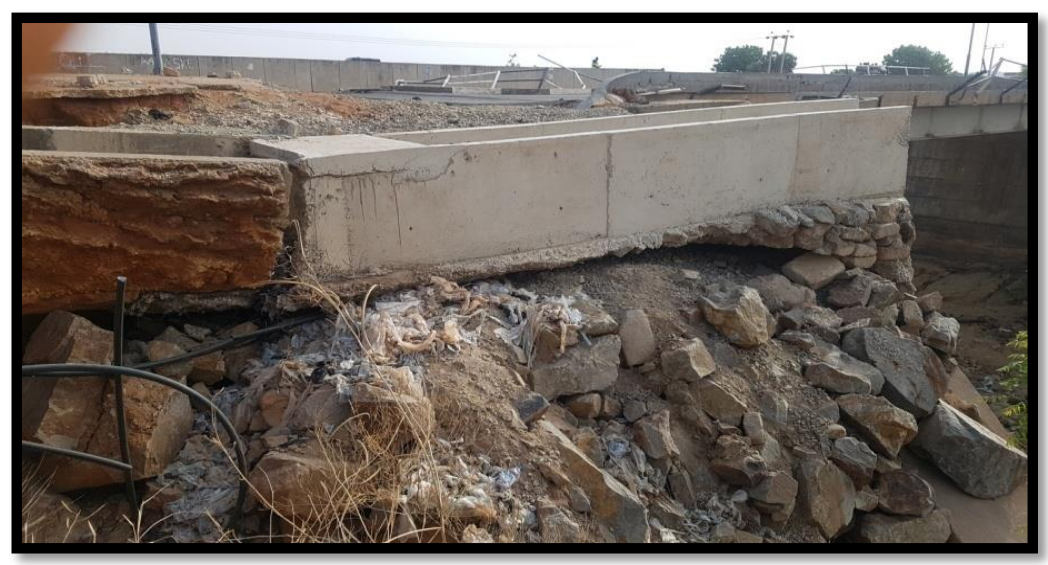

Figure 5: Image Showing Boulders Dump against Abutment



Figure 6: Image Showing Major Vertical Crack on Abutment

\section{Discussion of Result}

\subsection{Load Combination}

Type HA and HB load was included in the 1954 edition of BS 153: Part 3A. In 1961 the HB load was specified in terms of units and varied depending on the class of road, with 45 units required for Motorways and Trunk Roads and 37.5 units for class i and class ii roads. A requirement for all public roads to be designed for at least 30 units of HB was introduced in 1973 (David 2019)

Clause 6.2 type HA BS 5400 part 2: 2006 clause loading.

$\mathrm{H}_{\mathrm{A}}$ Loading covers- Impact (wheel bounce)

- Overloading

- Lateral buckling (more than one vehicular occupying lane)

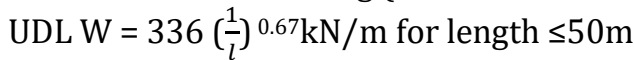

UDL $\mathrm{W}=36\left(\frac{1}{l}\right) 0.150 \mathrm{~m}<\mathrm{L}<1600 \mathrm{~m}$

$\mathrm{H}_{\mathrm{A}} \times \beta$ divided by the notional road lane 
KEL $x \beta$ may be positioned at any point for worst condition effect on member $120 \mathrm{kN}$ Where $\beta=0.0137\left[b_{\mathrm{L}}(40-\mathrm{L})+3.65(\mathrm{~L}-\right.$ 20)].

$\mathrm{H}_{\mathrm{A}}+\mathrm{KEL}$

$\mathrm{H}_{\mathrm{B}}$ Loading are exceptional loads e.g. (electrical transformers, generators, pressure vessels, machine presses etc.) likely to use the road way.

B D 37/01 chapter 4 is as follows

Motor way and truck roads require 45 units,

Principal road required 37.5 units,

Public roads require 30 units

One unit of $\mathrm{H}_{B}$ is equal to $10 \mathrm{kN}$ for axle, there are five $\mathrm{H}_{B}$ vehicles to check although most vehicles can be discounted by inspection. The spacing between the inner two axles of the vehicle has five different values which produces the range of $\mathrm{H}_{B}$ vehicle to consider.

Only one $\mathrm{H}_{B}$ vehicle is considered to load any one superstructure, $\mathrm{H}_{\mathrm{A}}$ loads is omitted if lane is within $25 \mathrm{~m}$. For design $\mathrm{H}_{\mathrm{A}}$ or $\mathrm{H}_{\mathrm{B}}$ loading giving the Worst condition is used to design the member.

Surcharge BS 5400 Part 2 clause 5.8.2;

For $\mathrm{H}_{\mathrm{A}}$ loading surcharging $=10 \mathrm{kN} / \mathrm{m}^{2}$

For $\mathrm{H}_{\mathrm{B}}$ loading surcharging $=20 \mathrm{kN} / \mathrm{m}^{2}$

Assume surcharge loading for the compaction plant to be equivalent to be 30 units of $H_{B}$, hence compaction plant surcharge $=12 \mathrm{kN} / \mathrm{m}^{2}$

FOR SURCHARGE OF $10 \mathrm{kN} / \mathrm{m}^{2}$

$\mathrm{F}_{\mathrm{S}}=\mathrm{k}_{\mathrm{a}} \mathrm{wh}=0.27 \mathrm{Wh} \mathrm{kN} / \mathrm{m}$

In the design of an abutment below are the loading combinations to be considered which ever gives the critical values of deformation should be taken for the final consideration.

Case 1 - Backfill + construction surcharge wall backfilled up to bearing level

Case $2-$ Backfill $+\mathrm{H}_{\mathrm{A}}$ surcharge + Deck dead load + Deck contraction

Case $3-$ Backfill $+\mathrm{H}_{\mathrm{A}}$ surcharge + braking behind abutment + deck dead load

Case $4-$ Backfill $+\mathrm{H}_{\mathrm{B}}$ surcharge + deck dead load

Case $5-$ Backfill $+\mathrm{H}_{\mathrm{A}}$ surcharge $=$ Deck dead load $+\mathrm{H}_{\mathrm{B}}$ on deck

Case $6-$ Backfill $+\mathrm{H}_{\mathrm{A}}$ surcharge + Deckdead load $+\mathrm{H}_{\mathrm{A}}$ on deck + Braking on deck (only applicable top fixed end abutment)

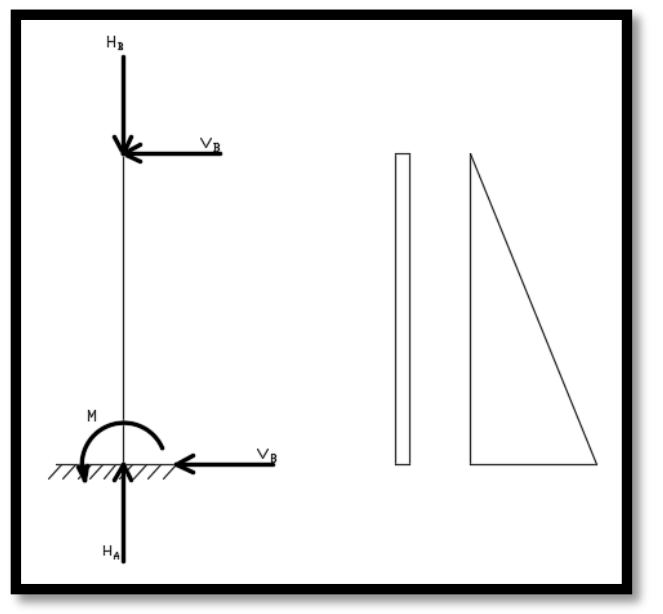

Figure 7

3.2. Analysis Consideration of Bridge Abutment across $9 \mathrm{~m}$ Width Road Way Spanning at 1.5m Spacing

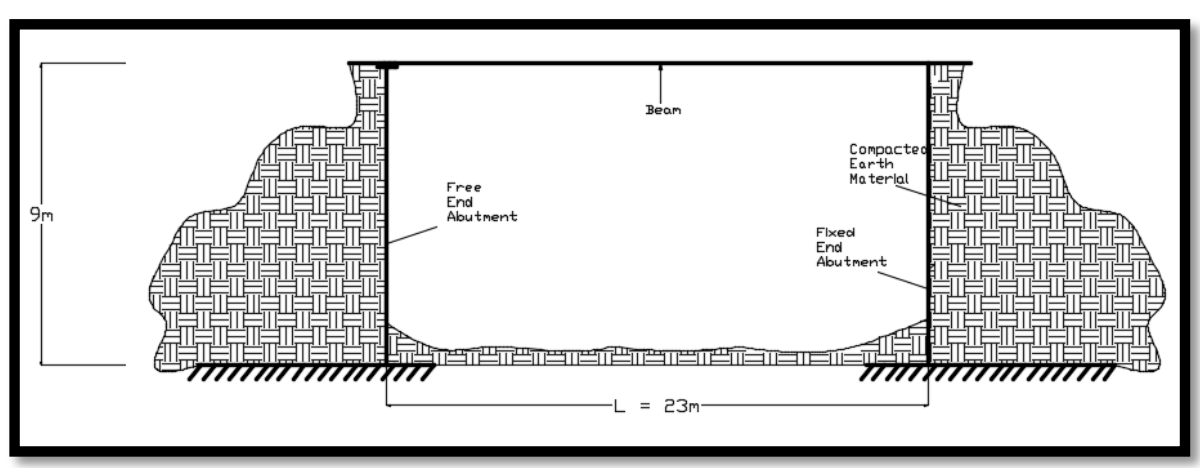

Figure 8 
3.2.1. Loading from Deck

Critical reaction under one beam

Concrete Deck + Surcharging $+\mathrm{H}_{\mathrm{B}}$ loading ultimate $=540 \mathrm{kN}$ UDL over abutment $1.5 \mathrm{~m}$ beam spacing. $=\frac{540 \mathrm{kN}}{1.5 \mathrm{~m}}=360 \mathrm{kN} / \mathrm{m}$ ultimate

Nominal load on abutment $=\frac{360 \mathrm{kN} / \mathrm{m}}{1.4}=257.14 \mathrm{kN} / \mathrm{m}$

$540 \mathrm{kN}$ to be used for elastomeric bearings

$257.14 \mathrm{kN} / \mathrm{m}$ is used for UDL over the length of the abutment.

\subsubsection{Analysis Consideration for Fixed Abutment}

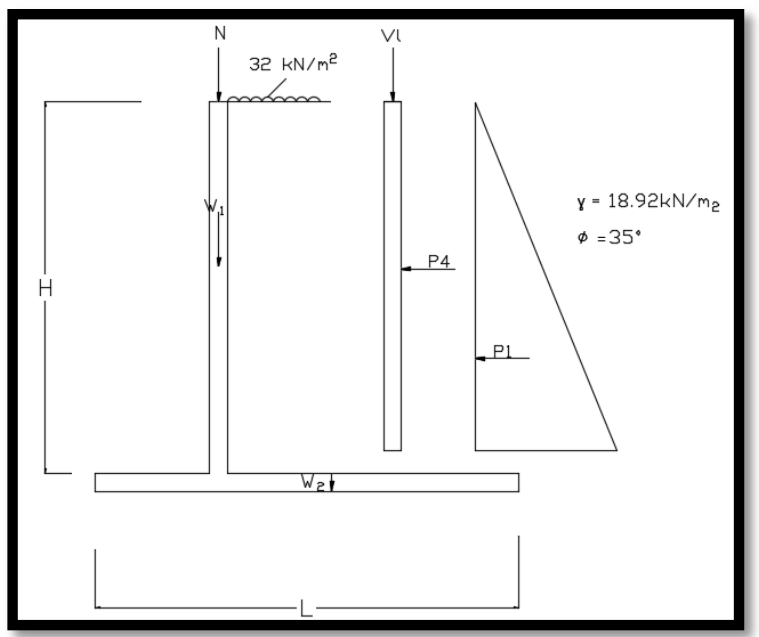

For $\mathrm{P}_{1}$

Figure 9

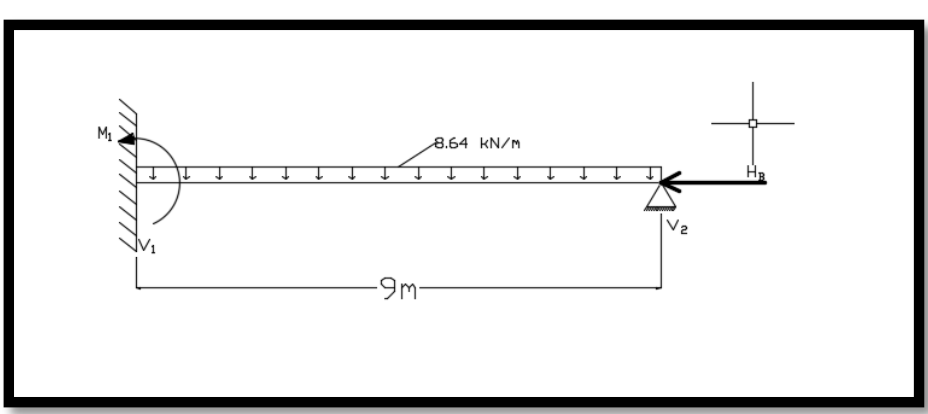

Figure 10

$\sum V_{\mathrm{F}}=0, \mathrm{~V}_{1}+\mathrm{V}_{2}-\mathrm{qL}=0$

$\sum M=0-\mathrm{M}_{1}+\mathrm{V}_{1} \mathrm{~L}-\frac{q l 2}{2}=0$

$\mathrm{V}_{2} \frac{-D O_{2}}{\mathrm{\gamma O}_{2}} \quad x=L$

$\mathrm{DO}_{2}=\int \frac{M_{O 2} x d x}{E I}, \mathrm{M}_{02}=\frac{q x^{2}}{2}$

$\frac{q}{2 E I} \int_{0}^{l} x^{3} d x, \frac{q}{2 E I} \int_{0}^{l} \frac{x^{4}}{4}=\frac{q l^{4}}{8 E I}$

$d_{o 2}=\int_{0}^{l} \frac{M}{E I} d x, \mathrm{M}^{-2}=\mathrm{x}^{2}$

$=\frac{1}{E} \int_{1}^{L} x^{2} d x=\frac{1}{E} \int_{0}^{l} \frac{x^{3}}{3}$

$\mathrm{d}_{\mathrm{o} 2}=\frac{x^{3}}{3 E I}, \quad x=L$

$\mathrm{V}_{2}=-\frac{\mathrm{D}_{o 2}}{d_{o 2}}=\frac{q l^{4}}{8 E I} \times \frac{3 E I}{x^{3}}$

$\mathrm{V}_{2}=\frac{3}{8} q l$

$\mathrm{V}_{2}=\frac{3 \times 8.64 \times 9}{8}=29.16 \mathrm{kN}$

$\sum V_{\mathrm{F}}=0, \mathrm{~V}_{1}+\mathrm{V}_{2}-\mathrm{qL}=0$

$\mathrm{V}_{1}+29.16-8.64 \times 9=0$

$\mathrm{V}_{1}=48.6 \mathrm{kN}$

$\sum M=0,-\mathrm{M}_{1}+\mathrm{V}_{1} \mathrm{~L}-\frac{q l 2}{2}=0$

$-\mathrm{M}_{1}+48.6 \times 9-\frac{8.64 \times 9^{2}}{2}=0$ 
$\mathrm{M}_{1}=87.48 \mathrm{kNm}$

$\mathrm{M}_{0}=-\frac{w\left\{\frac{4 l-l}{4}\right\}^{2}}{8}=-\frac{8.64\left\{\frac{4 \times 9-9}{4}\right\}^{2}}{8}=-49.21 \mathrm{kNm}$

For $\mathrm{P}_{2}$; representation of Load due to retained Material

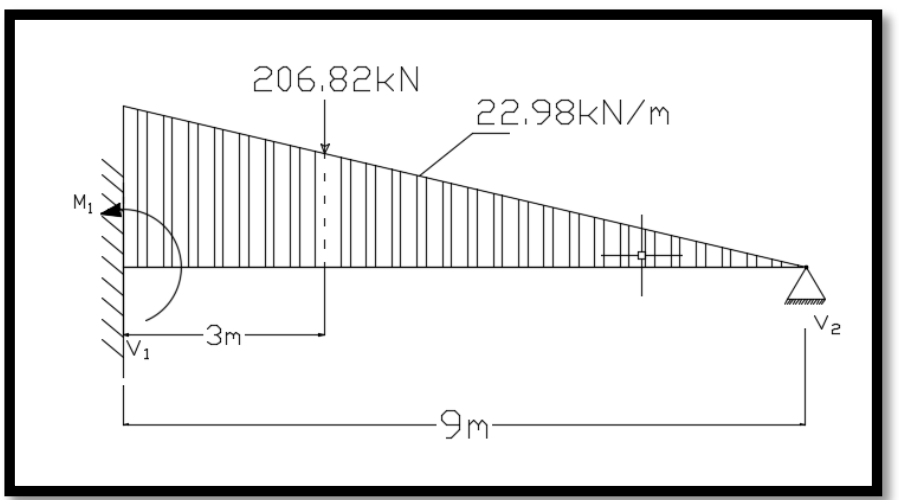

Figure 11

For $\mathrm{P}_{3}$; moment due to self-weight, assume the stem thickness of $800 \mathrm{~mm}$

Concrete self-weight $=24 \mathrm{kN} / \mathrm{m}^{3}$

Hence, $24 \mathrm{kN} / \mathrm{m}^{3} \times 0.8 \mathrm{~m} \times 1 \mathrm{~m}=19.2 \mathrm{kN} / \mathrm{m}$

$\mathrm{G}_{\mathrm{k}}=1.4 \times 19.2=26.88 \mathrm{kN} / \mathrm{m}$

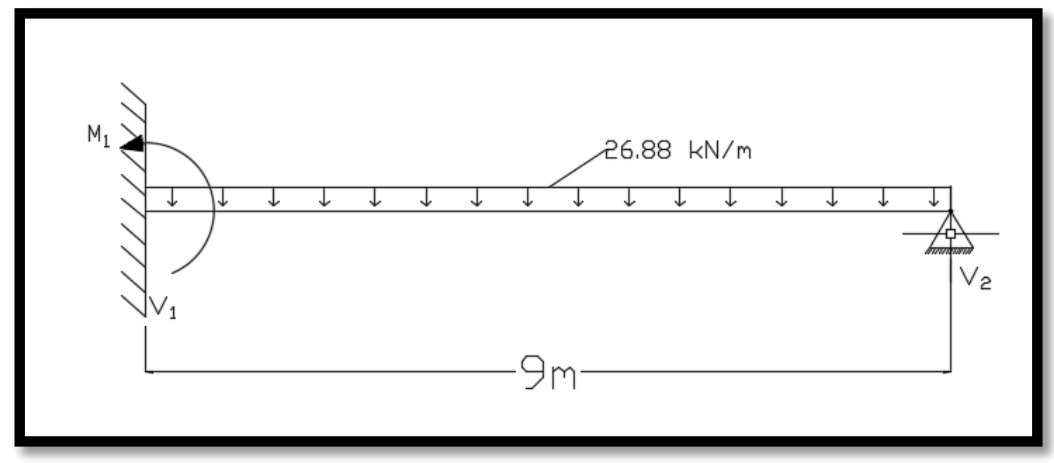

Figure 12

The table below shows the results for the analysis of the structure

\begin{tabular}{|c|c|c|c|c|c|}
\hline Reactions/Moment/Loads & $\mathbf{V}_{\mathbf{1}}(\mathbf{k N})$ & $\mathbf{V}_{\mathbf{2}} \mathbf{( k N )}$ & $\mathbf{M}_{\mathbf{1}} \mathbf{( k N m )}$ & $\mathbf{M}_{\mathbf{0}} \mathbf{( k N m )}$ & $\mathbf{q}(\mathbf{k N} / \mathbf{m})$ \\
\hline $\begin{array}{c}\text { Surcharge } \\
\left.\text { Weight ( } \mathrm{P}_{1}\right)\end{array}$ & -48.60 & 29.16 & -87.48 & 49.21 & -8.64 \\
\hline $\begin{array}{c}\text { Embankment } \\
\text { Material (P) }\end{array}$ & -82.87 & 20.76 & -124.34 & 55.63 & -22.98 \\
\hline $\begin{array}{c}\text { Concrete self } \\
\text { Weight (P) }\end{array}$ & -151.2 & 90.72 & -272.16 & 153.09 & -26.88 \\
\hline Total & -282.67 & 140.64 & -483.98 & 257.93 & -58.50 \\
\hline
\end{tabular}

Table 1: Stability of the Structure at the Tip/ Overturning Resistance 


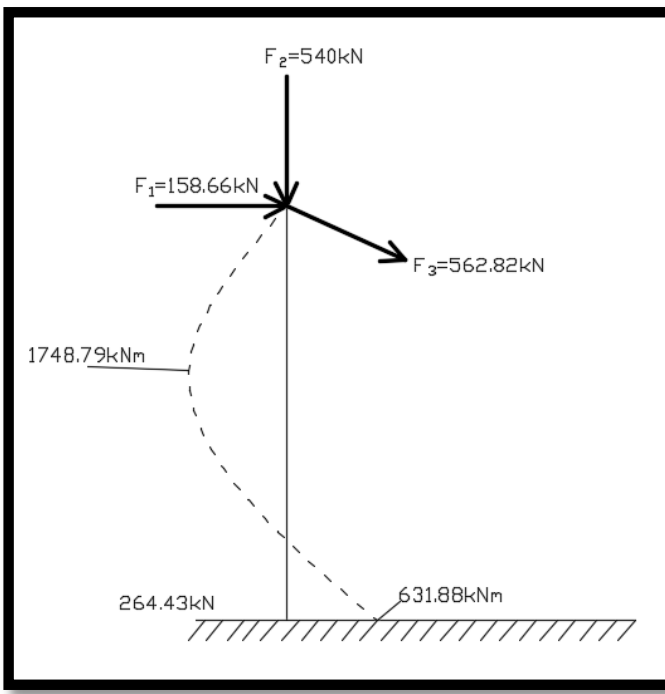

Figure 13

$558.01 \mathrm{kN} \times 9 \mathrm{~m}=5022.13 \mathrm{kNm}>483.98 \mathrm{kNm}$

The moment caused by F3 is greater than the moment caused by the retained load so the section is safer against Overturning.

The factor of safety is therefore

$$
\frac{5022.13 \mathrm{kNm}}{484.98 \mathrm{kNm}}=10.8
$$

To also check using the conventional method of Sliding check

$\mu 0.9\left(\sum\right.$ vertical forces $) \geq \gamma_{\mathrm{f}}\left(\sum\right.$ horizontal forces $)$

$\mu=0.5$, vertical forces

$0.5 \times 0.9(782+188.6+1050.9)=909.6 \mathrm{kN}$

$\mathrm{\gamma}_{\mathrm{f}}=1.6$, Horizontal forces

$1.6(77.6+119.41)=315.216 \mathrm{kN}$

It shows that $909.6 \mathrm{kN}>315.22 \mathrm{kN}$

The Factor of safety becomes $\frac{909.6 \mathrm{kN}}{315.22 \mathrm{kN}}=2.8$

Therefore, base heel not needed. It is able to resist sliding, just as it shown above the stability at the tip is satisfactory.

3.2.2.1. Loading at the Base

$\mathrm{W}_{1}=1.4 \times 24 \times 0.8 \times 9 \times 1=242 \mathrm{kN}$

$540 \mathrm{kN}+242 \mathrm{kN}=784 \mathrm{kN}$

Base load $=\mathrm{f}_{\mathrm{s} Y \mathrm{c}} \mathrm{b} \mathrm{h} \mathrm{w}$

$\mathrm{W}_{2}=1.4 \times 24 \times 0.8 \times 7 \times 1=188.16 \mathrm{kN}$.

Earth load $=\gamma_{s}$ h Wh

$18.92 \times 9 \times 5.2 \times 1=884.52 \mathrm{kN}$

Surcharge load $=32 \mathrm{kN} / \mathrm{m} \times 5.2=166.4 \mathrm{kN}$

Earth load + surcharge load $=884.52 \mathrm{kN}+166.4 \mathrm{kN}=1050.29 \mathrm{kN}$

3.2.2.2. Presentation of Loading on Base Structure

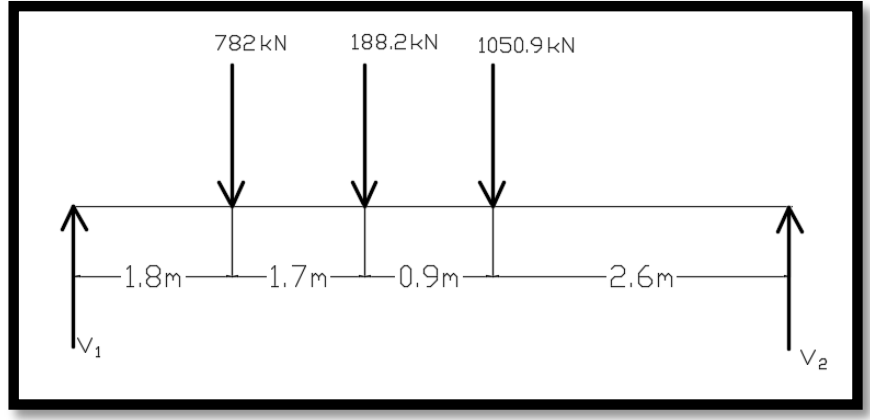

Figure 14 


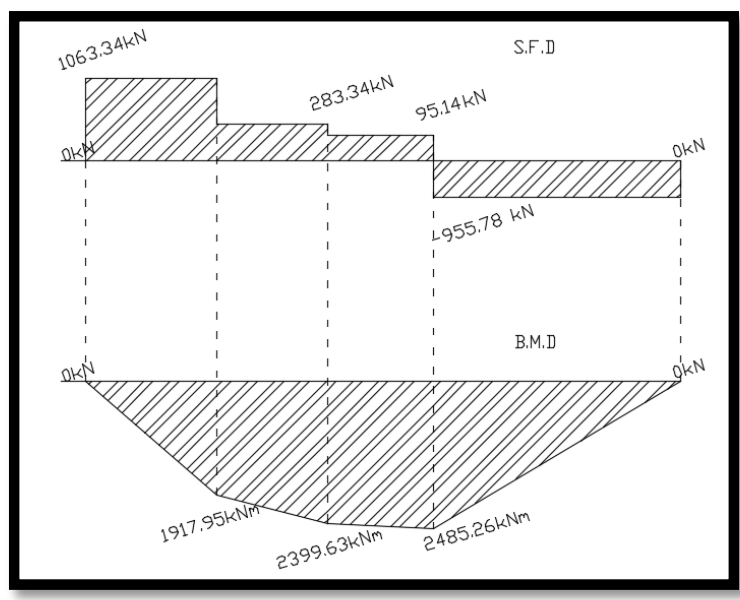

Figure 15

\subsubsection{Check for Earth Pressure}

$$
\text { From } P=\frac{W}{B D} \pm \frac{6 M}{B D^{2}}
$$

Where $\mathrm{B}=1000, \mathrm{D}=7000$

Moment about the center of gravity of the structure

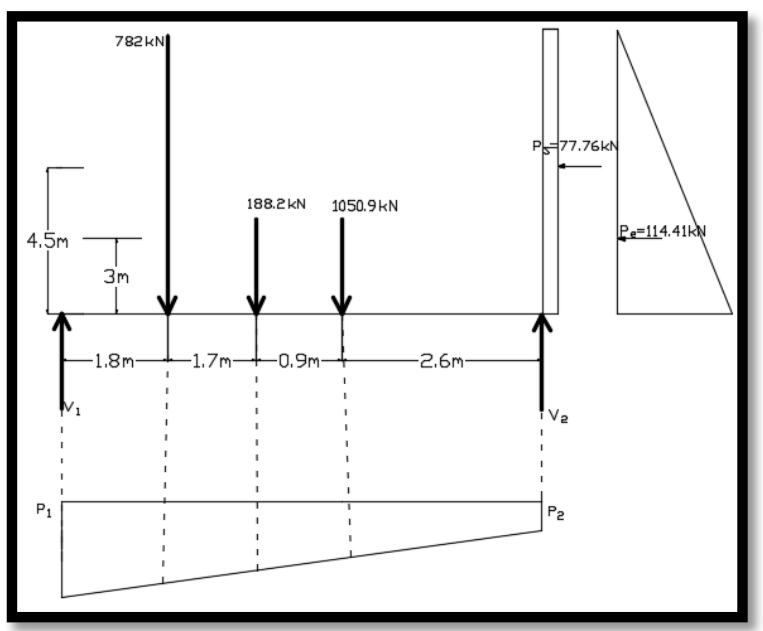

Figure 16

Moment about the center of gravity of the structure clockwise

$\mathrm{P}_{\mathrm{e}}=1050.92 \times 0.9=945.83 \mathrm{kNm}$

Counter clockwise pressure active

$77.7 \times 4.5+119.41 \times 3+782 \times 1.7=2037.28 \mathrm{kNm}$

Net moment $=$ clockwise - anti-clockwise

$2037.28-945.83=1091.45 \mathrm{kNm}$

$\mathrm{W}=782+188.16+1050.92=2021.08 \mathrm{kN}$

$\mathrm{P}_{1}=\frac{2021.08}{7 \times 1}+\frac{1091.45 \times 6}{1 \times 7^{2}}$

$\mathrm{P}_{1}=288.7+133.64=422.35 \mathrm{kN} / \mathrm{m}$

$\mathrm{P}_{2}=288.7-133.64=155.07 \mathrm{kN} / \mathrm{m}$

The maximum bearing pressure P1 should be less than the allowable bearing capacity of the soil, the structure will be founded upon. Should the bearing pressure $\mathrm{P}$ exerted by the structure is greater than the soil bearing pressure alternative for choice of foundation is needed. For example, assume the bearing pressure of the soil was $150 \mathrm{kN} / \mathrm{m}^{2}$ will not be suitable for the design of spread or Pad footing. Hence, Pile foundation is needed. 


\subsubsection{Analysis Consideration on Free End Abutment}

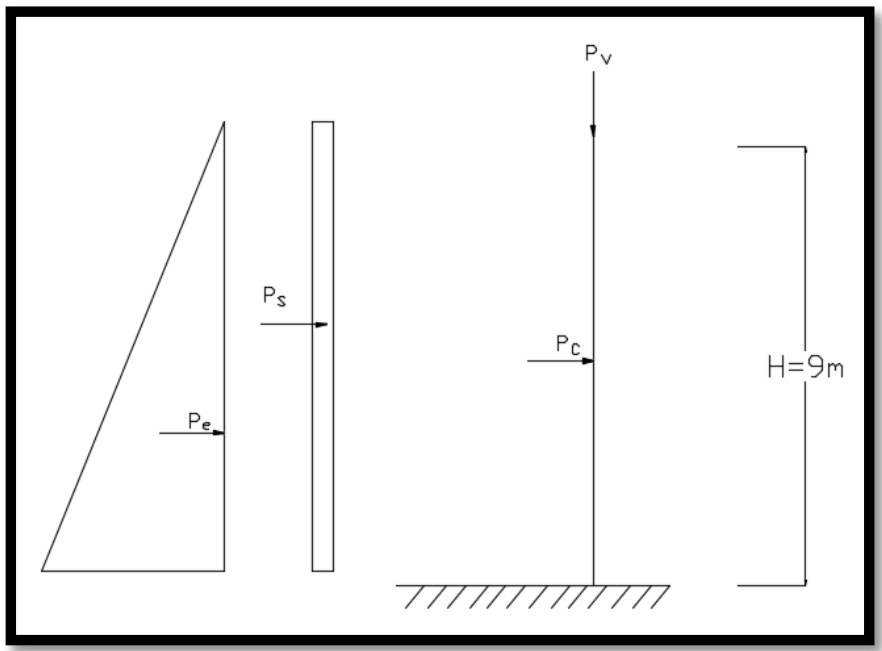

Figure 17

Horizontal loading of the fixed abutment

$\mathrm{Pe}=0.5 \mathrm{k}_{\mathrm{a}} \mathrm{wh} \mathrm{KN} / \mathrm{m}, \mathrm{ka}=0.27, \mathrm{~h}=9 \mathrm{~m}, \mathrm{w}=18.92 \mathrm{KN} / \mathrm{m}^{3}$

Load due to earth retained $\mathrm{Pe}=0.5 \times 0.2 \times 18.92 \times 9=22.98 \mathrm{kN} / \mathrm{m}$

$\mathrm{Pe}=22.98 \mathrm{kN} / \mathrm{m} \times 9 \mathrm{~m}=206.82 \mathrm{kNacts}$ at $1 / 3$ length of the base

$\mathrm{Ps}=\mathrm{kawka}=0.27, \mathrm{w}=32 \mathrm{kN} / \mathrm{m}$

Load due to surcharge Ps $=0.27 \times 32=8.64 \mathrm{kN} / \mathrm{m}$

$\mathrm{Ps}=8.64 \mathrm{kN} / \mathrm{m} \times 9 \mathrm{~m}=77.76 \mathrm{kN}$ acts at the middle length

Because it is a free end abutment, and so will be treated as a cantilever structure

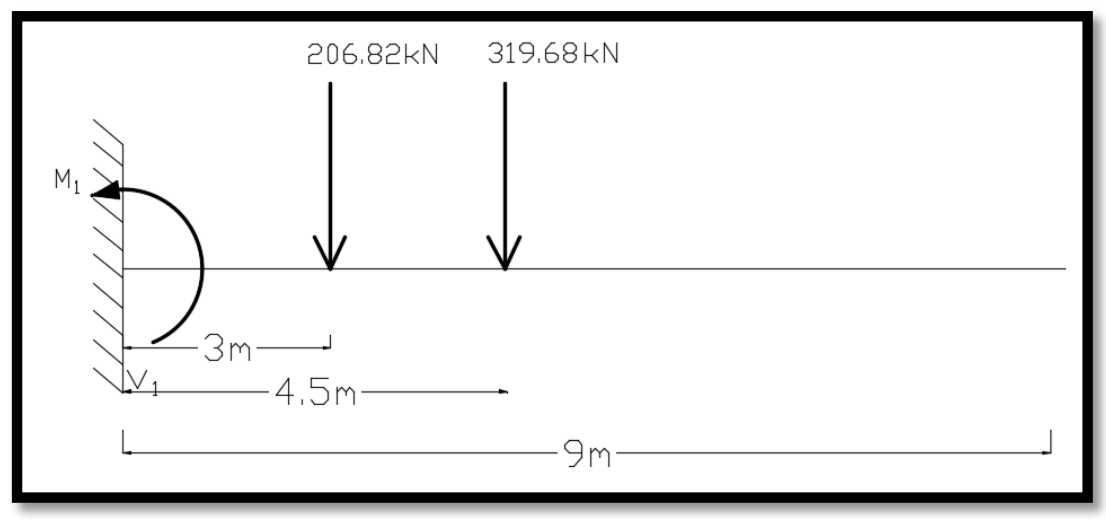

Figure 18

$$
\begin{array}{ll}
\sum V_{F}=0 & \mathrm{~V}_{1}=-206.82-77.76=0 \\
\sum M=0 & \mathrm{~V}_{1}=284.58 \mathrm{kN} \\
& -\mathrm{M}_{1}-206.82 \times 3-77.6 \times 4.5=0 \\
& -\mathrm{M}_{1}-620.46-349.2=0 \\
& \mathrm{M}_{1}=-969.66 \mathrm{kNm}
\end{array}
$$

Design formula used to BS 8110-1997 reinforced concrete design Using BS8110 $\mathrm{f}_{\mathrm{y}}=410 \mathrm{~N} / \mathrm{mm}^{2}, \mathrm{f}_{\mathrm{cu}}=30 \mathrm{~N} / \mathrm{mm}^{2}$

$\mathrm{A}_{\mathrm{s}}=\frac{M}{0.95 f_{y} z}, \mathrm{k}=\frac{M}{b d^{2} f_{c u}}$

Where $\mathrm{k}>0.156$, Compression reinforcement will be needed.

$\mathrm{A}_{\mathrm{s}}=\frac{M-0.15 f_{c u} b d^{2}}{0.95 f_{y}\left(d-d^{1}\right)}, \mathrm{A}_{\mathrm{s}}=\frac{0.156 f_{c u} b d}{0.95 f_{y}}+\mathrm{A}_{\mathrm{s}}{ }^{1}$

For distribution reinforcement

Minimum area, $A_{s}=\frac{0.13 b h}{100}$ 


\begin{tabular}{|c|c|c|c|c|c|c|c|c|c|c|c|}
\hline 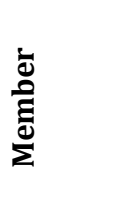 & 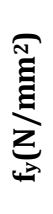 & 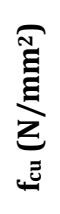 & 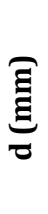 & 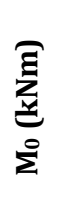 &  & $\sum_{\Sigma}^{\pi}$ & 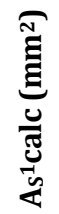 & 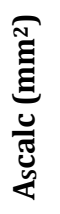 & 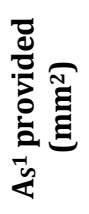 &  & 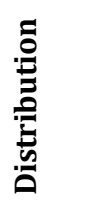 \\
\hline \multirow[t]{2}{*}{ 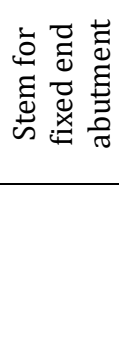 } & $\stackrel{\circ}{\vec{\gamma}}$ & pे & $\stackrel{P}{+}$ & 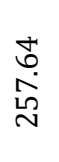 & & $\stackrel{m}{\sigma}$ & & $\begin{array}{l}\stackrel{m}{m} \\
\text { in } \\
\text { م⿱ } \\
\text { N }\end{array}$ & & 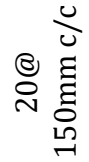 & 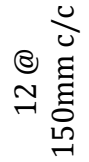 \\
\hline & $\stackrel{\circ}{\vec{\gamma}}$ & $\stackrel{m}{ }$ & $\stackrel{\text { P }}{+}$ & & $\begin{array}{l}\infty \\
\stackrel{\infty}{\infty} \\
\infty \\
\infty \\
\alpha\end{array}$ & $\begin{array}{l}\hat{\infty} \\
\stackrel{0}{0}\end{array}$ & & 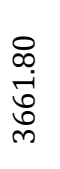 & & 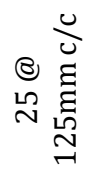 & 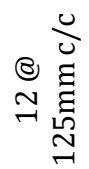 \\
\hline 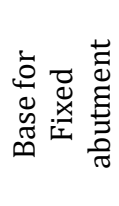 & $\stackrel{\circ}{\stackrel{y}{f}}$ & iి & $\stackrel{8}{\circ}$ & $\begin{array}{l}\text { m. } \\
\stackrel{0}{0} \\
\stackrel{+}{N}\end{array}$ & & 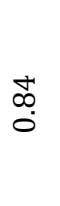 & $\begin{array}{l}\infty \\
0 \\
0 \\
0 \\
0 \\
\ddots 1\end{array}$ & $\begin{array}{l}\stackrel{0}{\stackrel{1}{*}} \\
\stackrel{-1}{2}\end{array}$ & 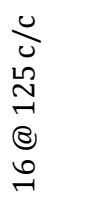 & 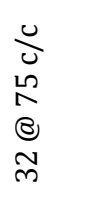 & 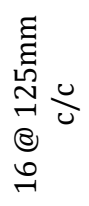 \\
\hline 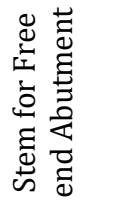 & $\stackrel{0}{\vec{f}}$ & 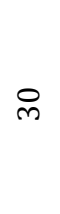 & में & $\begin{array}{l}\text { ठ̊. } \\
\stackrel{0}{ }\end{array}$ & & $\stackrel{-1}{0}$ & & $\begin{array}{l}0 \\
\text { กn. } \\
0 \\
\infty \\
\overrightarrow{6}\end{array}$ & & 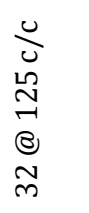 & 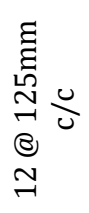 \\
\hline 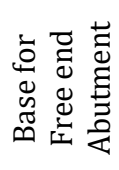 & $\vec{F}$ & pे & $\stackrel{8}{\circ}$ & 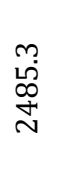 & & $\begin{array}{l}\hat{0} \\
\stackrel{0}{0}\end{array}$ & $\begin{array}{l}\infty \\
o \\
0 \\
0 \\
\ddots \\
=\end{array}$ & $\begin{array}{l}\stackrel{0}{s} \\
\stackrel{1}{1} \\
\text { ñ }\end{array}$ & 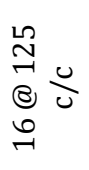 & 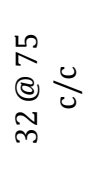 & 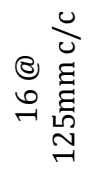 \\
\hline
\end{tabular}

Table 2: Table for Result

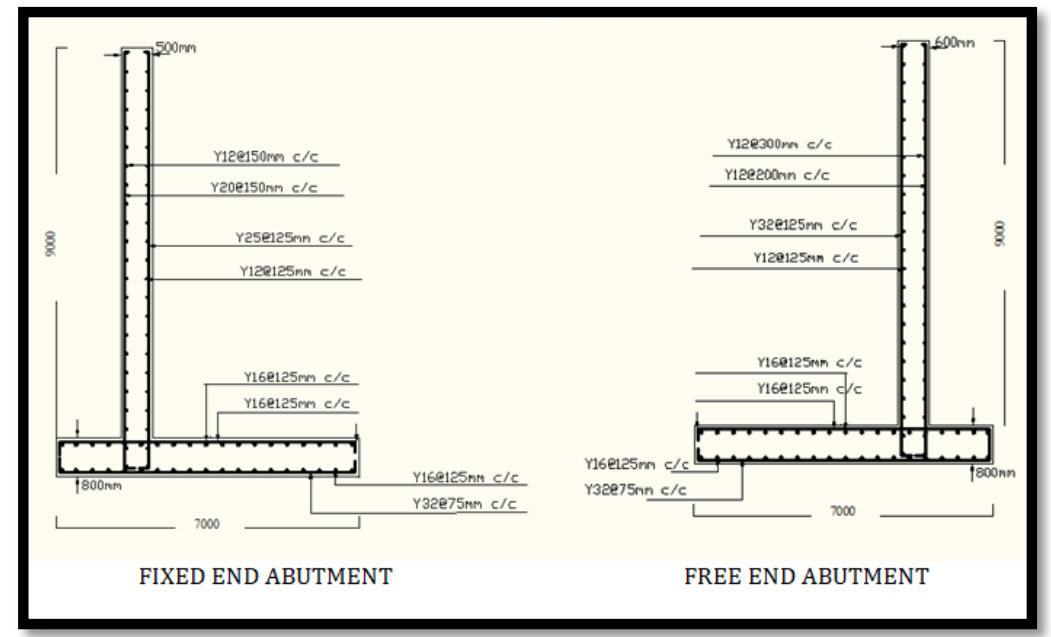

Figure 19: Detailed Drawings

\subsection{Observation}

- Tensile moment is greater at the free abutment at the free end abutment than at the fixed end abutment. Owning thicker section in comparison to the fixed end abutment.

- The bearing pressure exerted by the abutment is $422.35 \mathrm{kN} / \mathrm{m} 2$ maximum.

- The resultant force acted at the fixed end abutment by the effective length of the abutment (moment) greater than the moment caused by the lateral loads is adequate to restrain overturn.

\section{Conclusion}

Bridge abutment, should therefore be design base on functional and capability to avoid failure as mostly in practiced, single design abutment (free abutment) repeated for the alternative. The knowledge gained through this case 
study should lead to the development of a model for the management of abutment movement in Nigeria bridges abutment so as to easily detect faulty abutment.

\section{Recommendation}

If the bearing pressure of the soil of which the abutment will be founded on, is less than the exerted bearing pressure by the abutment, pile foundation will be required to restrain sinking. For wider spacing of stem and base reinforcement, effective depth may be increase.

\section{References}

i. Alan W., (2008) Structural Analysis in Theory and Practice Jennings H.B. (2004). Structures from Theory to Practice. ISBN 9780415268431

ii. Charles E. Reynolds and et-al (2008). Reinforced Concrete Designer's Handbook, Tenth Edition

iii. Child D. (2019) Bridge Design and Assessment. Bridgedesign.org.uk/bridgedesign.php

iv. Conner D. H. (2013) Behavior and Analysis of an Integral Abutment Bridge

v. Ghali A., Neiville A., and Brown T.G. (2015) Structural analysis, 5th edition Kharagpur, (2008) Structural Analysis

vi. Macginley, T. J. and Choo, B.S. (nd). Reinforced concrete design theory and example, 2nd Edition

vii. Robert E., KamNg., Ram C., \& Joshua Fuller (2015). Failure of spill through bridge abutment during scur, flame and field observation. 'journal of hydraulic engineering 141(5)

viii. W. M. C. Mckenzie, (2006). Examples in Structural Analysis 